\title{
Assessment of the Effectiveness of Ectomycorrhizal Inocula to Promote Growth and Root Ectomycorrhizal Colonization in Pinus patula Seedlings Using the Most Probable Number Technique
}

\author{
Manuel Restrepo-Llano, Nelson W. Osorio, and Juan D. León \\ Universidad Nacional de Colombia, Calle 59 No. 63-20, 050034 Medellín, Colombia \\ Correspondence should be addressed to Juan D. León; jdleon@unal.edu.co
}

Received 26 July 2014; Revised 23 November 2014; Accepted 25 November 2014; Published 8 December 2014

Academic Editor: Teodoro M. Miano

Copyright (C) 2014 Manuel Restrepo-Llano et al. This is an open access article distributed under the Creative Commons Attribution License, which permits unrestricted use, distribution, and reproduction in any medium, provided the original work is properly cited.

\begin{abstract}
The aim of this study was to evaluate the response of Pinus patula seedlings to two inocula types: soil from a Pinus plantation (ES) and an in vitro produced inoculum (EM). The most probable number method (MPN) was used to quantify ectomycorrhizal propagule density (EPD) in both inocula in a 7-order dilution series ranging from $10^{\circ}$ (undiluted inoculum) to $10^{-6}$ (the most diluted inoculum). The MPN method allowed establishing differences in the number of infective ectomycorrhizal propagules' density (EPD) (ES = 34 per g; EM = 156 per g). The results suggest that the EPD of an inoculum may be a key factor that influences the successfulness of the inoculation. The low EPD of the ES inoculum suggests that soil extracted from forest plantations had very low effectiveness for promoting root colonization and plant growth. In contrast, the high EPD found in the formulated inoculum (EM) reinforced the idea that it is better to use proven high quality inocula for forest nurseries than using soil from a forestry plantation.
\end{abstract}

\section{Introduction}

It is broadly recognized that ectomycorrhizal associations play a key role in the nutritional status and growth of forest plants [1-3] and, in some cases, their presence is essential for such plants [2]. One of these plants is Pinus patula, a species with great economic importance worldwide [4]. The success of $P$. patula plantations depends on the establishment of ectomycorrhizal associations with certain fungal species [5-7].

The ectomycorrhizal association has been demonstrated as an outstanding symbiotic mechanism for $P$. patula silviculture because (a) it promotes seedling growth and nutrient uptake during the nursery stage [2], (b) it reduces nutrient additions within nursery management programs [8], and (c) it protects the roots against soil-borne pathogens $[2,9]$.

It has been accepted that the addition of a formulated ectomycorrhizal inoculum for $P$. patula seedlings effectively induces the establishment of ectomycorrhizas features in the roots in comparison with the spontaneous and natural colonization from native propagules $[2,7,10]$. Despite the importance of inoculation for promoting plant growth, little is known about the quality of ectomycorrhizal inocula or inoculum type, which has limited the scale of their use.

We hypothesize that the growth and root ectomycorrhizal colonization of $P$. patula seedlings are affected by ectomycorrhizal propagule density (EPD) and it can be used as an indicator of inoculum quality. From a practical point of view, it will help nursery producers and governmental authorities to regulate inoculum standards to be used. In this study, we propose that the most probable number (MPN) method [11] may be used to quantify the EPD in different inocula capable of promoting $P$. patula seedling growth and root colonization. Furthermore, this method may be used to examine the effectiveness of techniques traditionally used to produce ectomycorrhizal inocula: (i) the extraction of soil from $P$. patula plantations $[8,12,13]$ and (ii) in vitro production of fungal inoculum [14]. 


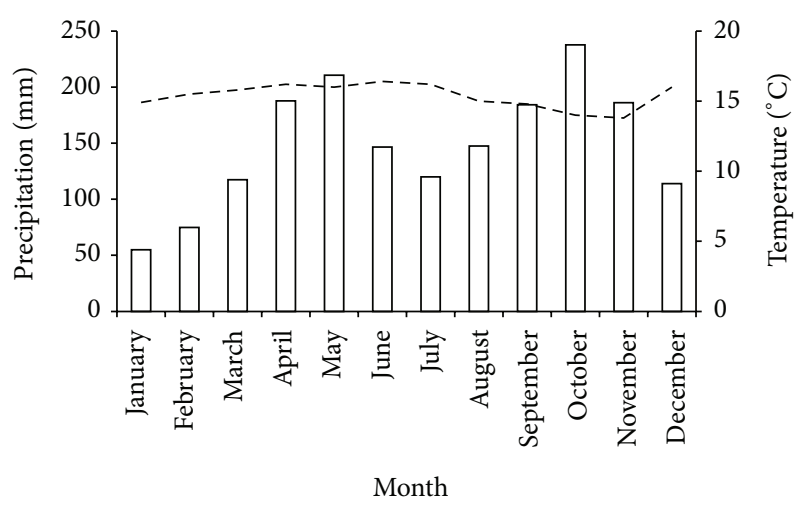

FIGURE 1: Monthly precipitation and mean temperature values along 2013.

\section{Materials and Methods}

2.1. Site. The experiment was carried out in Santa Elena, Medellin, Colombia $\left(06^{\circ} 15^{\prime} 25.6^{\prime \prime} \mathrm{N}, 75^{\circ} 30^{\prime} 08.2^{\prime \prime} \mathrm{W}\right)$, at an altitude of $2500 \mathrm{~m}$. In this area, the mean annual precipitation is $1760 \mathrm{~mm}$ and the mean temperature is $15^{\circ} \mathrm{C}$ (Figure 1).

2.2. Soil/Substrate. The substrate was obtained by thoroughly mixing a soil with sand $(3: 1, \mathrm{~V}: \mathrm{V})$; the soil was collected from a surface horizon (horizon A, $0-25 \mathrm{~cm}$ ). This soil was classified as Melanudand (volcanic ash soil) and was under grass coverage at the time of collection. Soil tests were conducted at the Biogeochemistry Laboratory at the Universidad Nacional de Colombia at Medellín (soil pH 5.6, organic matter content $16.4 \%$, Bray No. 2-phosphorus $2 \mathrm{mg} \mathrm{kg}^{-1}$, and $1 \mathrm{M}$ ammonium acetate- $\mathrm{Ca},-\mathrm{Mg}$, and $-\mathrm{K} 2.8$, 0.5 , and $0.12 \mathrm{cmol}_{\mathrm{c}} \mathrm{kg}^{-1}$, resp.). The substrate was sterilized with Basamid (active ingredient dazomet: 3,5-dimethyl-1,3,5thiadiazinane-2-thione) with a dose application of $200 \mathrm{~g} / \mathrm{m}^{3}$. The sterilized substrate was covered with a plastic sheet for two weeks and then aerated for five days. After this time period, the substrate received $3 \mathrm{~kg} \mathrm{~m}^{-3}$ of a commercial fertilizer grade 10-30-10.

2.3. Fungal Inocula Treatments. Two ectomycorrhizal inocula were used in this study. The first inoculum corresponded to an undetermined mixture of two ectomycorrhizal species (Amanita muscaria and Suillus luteus), which was multiplied under in vitro conditions. The culture medium potatodextrose-agar ( $15 \mathrm{~g}$ per L) used was previously autoclaved $\left(120^{\circ} \mathrm{C}, 0.1 \mathrm{MPa}, 20 \mathrm{~min}\right)$; after a period of incubation of 10 days at $25^{\circ} \mathrm{C}, 5 \mathrm{~mL}$ of this broth was mixed with $1 \mathrm{~kg}$ of autoclaved soil and was named ectomycorrhizal mixture (EM). The second inoculum was obtained from a soil collected from the A horizon $(0-25 \mathrm{~cm})$ in a $P$. patula plantation [9]; besides soil it contained roots and ectomycorrhizal propagules of the fungi Amanita muscaria, Amanita sp., and Suillus luteus, which have been observed around the trees of $P$. patula roots; this inoculum was labeled ectomycorrhizal soil (ES) and its collection was accomplished by excavating the soil surface and putting it into sterile containers for a week until the inoculation time. This latter inoculum is traditionally used in local nurseries.

2.4. MPN Technique. We used the most probable number (MPN) technique, which is based on the presence or absence of particular features linked to the target microorganism effects in a serial dilution of infected media [15]. In this case, the attribute selected was the presence or absence of ectomycorrhizal structures in the roots of $P$. patula seedlings, as described by Dames et al. [16]. We diluted $320 \mathrm{~g}$ of the inoculum (one part) in $2880 \mathrm{~g}$ (nine parts) for obtaining $3200 \mathrm{~g}$ of the first dilution; it represented a $10^{-1}$ dilution and was used for 16 seedlings in bags with capacity for $180 \mathrm{~g}$ (=3200 g). Subsequently, the second dilution $\left(10^{-2}\right)$ was prepared from the $10^{-1}$ dilution keeping the same proportions. The procedure was repeated until obtaining the $10^{-6}$ dilution. As a control treatment, we also used undiluted inocula as a growth substrate (without dilution, named $10^{\circ}$ ). This substrate of each dilution was used to fill 16 plastic bags $\left(6 \times 12 \mathrm{~cm}, 160 \mathrm{~cm}^{3}\right)$, with $180 \mathrm{~g}$ per bag.

2.5. Plant Growth Conditions. Certified seeds of P. patula, obtained from the Santa Elena nursery (Vereda Mazo, Medellin, Colombia), were germinated in sterile sand for 10 days. At this moment the seedlings were transplanted into plastic bags (one per bag) containing inoculated substrate. After 30 days, the seedlings were sprayed monthly with the fertilizer Wuxal (20-0-15). The nursery growth period lasted from February to June 2013 (five months).

2.6. Experimental Design. We used a completely randomized experimental design. All seedlings occupied a surface area of $8 \mathrm{~m}^{2}$ and were exposed to the same weather conditions without any gradient of moisture, slope, shade, and wind. Treatments had a factorial $2 \times 7$ arrangement, that is, two inocula (EM, ES) and seven dilution series $\left(10^{0}, 10^{-1}, 10^{-2}\right.$, $10^{-3}, 10^{-4}, 10^{-5}$, and $\left.10^{-6}\right)$. Each treatment had 16 replicates.

2.7. Variables. We measured plant height in all replicates at harvest time (150 days after germination). We also measured root ectomycorrhizal colonization using the gridline intersection method as described by Brundrett et al. [17]. The resulting data were used to estimate the MPN of ectomycorrhizal propagules density (EPD) using the probabilistic table developed by Cochran [11]. Thus, from each treatment group, only five seedlings were randomly selected to check for ectomycorrhizal colonization as indicated in the method. Root collar diameter and shoot dry weight (after ovendrying the plant material at $65^{\circ} \mathrm{C}, 72 \mathrm{~h}$ ) were measured in all replicates.

2.8. Data Analysis. Data were analyzed using ANOVA and the LSD mean separation test. Both tests were conducted with a significance level $(P) \leq 0.005$. The tests were performed with the software R (R Studio 0.98.501) [18]. 


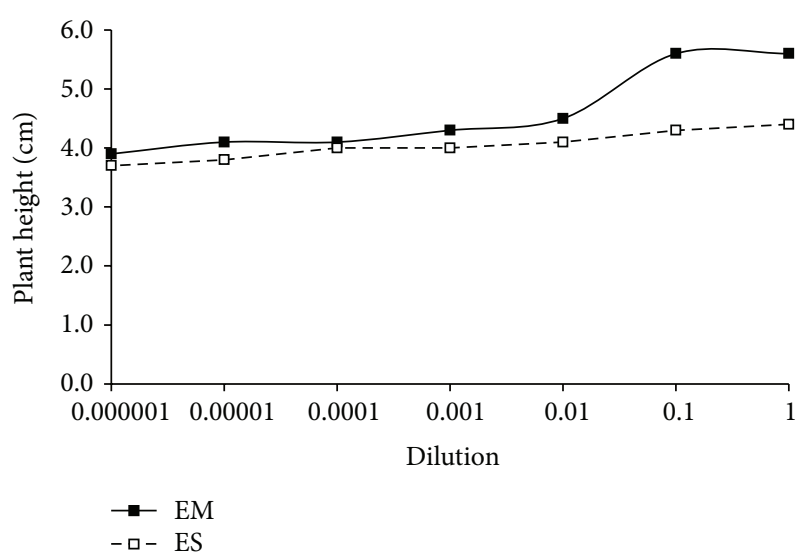

FIgUre 2: Plant height of $P$. patula seedlings as a function of EM and ES inoculation at each level of serial dilution.

TABLE 1: Number of roots (of five) with presence of ectomycorrhizal features and estimated ectomycorrhizal propagule density (EPD) per gram of substrate.

\begin{tabular}{lccccccc}
\hline \multirow{2}{*}{ Inoculum } & \multicolumn{7}{c}{ Dilution } \\
& $10^{-1}$ & $10^{-2}$ & $10^{-3}$ & $10^{-4}$ & $10^{-5}$ & $10^{-6}$ & EPD per g \\
\hline EM & 5 & 5 & 4 & 3 & 3 & 3 & 156 \\
ES & 4 & 4 & 4 & 4 & 3 & 3 & 34 \\
\hline
\end{tabular}

\section{Results}

The MPN technique allowed us to separate inoculum based on the estimated EPD. The results indicated that EM and ES had 156 and 34 ectomycorrhizal propagules per gram of inoculum (Table 1). These values will explain the differential effects observed between both inocula on plant performance. In fact, the inoculum type and dilution treatments significantly affected $P$. patula seedling growth and ectomycorrhizal colonization of roots (Table 2). Interactive effects of both factors were detected on plant height and shoot dry weight but not on root collar diameter and root ectomycorrhizal colonization.

Values of all variables showed a tendency to decrease as the dilution increased. For instance, in the case of plant height, values ranged between $3.7 \mathrm{~cm}$ (ES inoculum) and $3.9 \mathrm{~cm}$ (EM inoculum) with the most diluted treatment $\left(10^{-6}\right.$ dilution), while those with the least diluted treatment $\left(10^{-1}\right.$ dilution) had values of $4.3 \mathrm{~cm}$ and $5.6 \mathrm{~cm}$, respectively. This represented a relative increase of 16 and $44 \%$, respectively (Table 2, Figure 2). The difference associated with inoculum type was evident in the $10^{-1}$ dilution and in the undiluted treatment. Thus, at the $10^{-1}$ dilution seedlings inoculated with EM and ES reached a plant height of $5.6 \mathrm{~cm}$ and $4.3 \mathrm{~cm}$, respectively, which means $30 \%$ of relative difference. When $P$. patula seedlings grew in the EM and ES undiluted inocula, the plant heights were $5.6 \mathrm{~cm}$ and $4.4 \mathrm{~cm}$ (27\% difference), respectively.

A similar pattern was detected with the shoot dry weights; with the most diluted ES treatment $\left(10^{-6}\right)$ the shoot dry weight was $0.6 \mathrm{~g}$ per plant, while with the least diluted $\left(10^{-1}\right)$

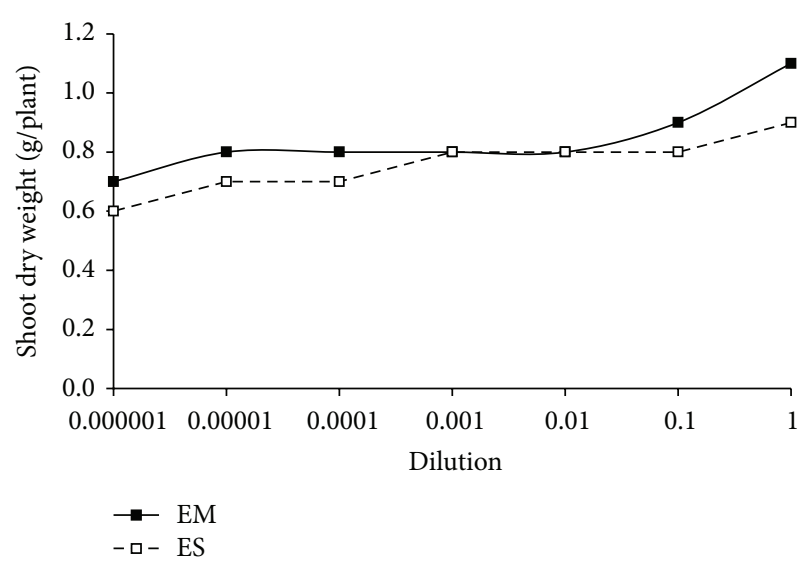

FIgURE 3: Shoot dry weight of $P$. patula seedlings as a function of $\mathrm{EM}$ and ES inoculation at each level of serial dilution.

it was $0.9 \mathrm{~g}$ per plant ( $50 \%$ of relative increase). With the EM inocula the respective shoot dry weights were $0.7\left(10^{-6}\right.$ dilution) and $1.1\left(10^{-1}\right.$ dilution) g per plant which represent $64 \%$ of relative increase (Table 2 , Figure 3 ). In general, the shoot dry weights of seedling inoculated with EM inoculum were higher than with ES inoculum, which was more evident in the $10^{-1}$ dilution and in the undiluted treatment. Thus, at the $10^{-1}$ dilution seedlings inoculated with EM and ES reached a shoot dry weight of $0.9 \mathrm{~cm}$ and $0.8 \mathrm{~g}$ per plant, respectively, which means $13 \%$ of relative difference. When $P$. patula seedlings grew in the EM and ES undiluted inocula, the shoot dry weights were 1.1 and $4.4 \mathrm{~g}$ per plant $(22 \%$ difference), respectively. On the other hand, the root collar diameter values were higher for seedlings grown in the most concentrated inocula $\left(10^{-1}\right)$ than in the most diluted $\left(10^{-6}\right)$ (Figure 4); however, this variable seemed to be less sensitive to treatments than the other variables.

Root ectomycorrhizal colonization presented the highest values with the undiluted inocula of $31.6 \%$ with EM inoculum and 23.6\% with ES inoculum (Figure 5). All seedlings assessed developed at least an incipient degree of ectomycorrhizal colonization. For both inocula, seedlings grown in the highest dilution $\left(10^{-6}\right)$ presented the lowest root ectomycorrhizal colonization, $10.4 \%$ with EM inoculum and $15.8 \%$ with ES inoculum.

\section{Discussion}

The results clearly demonstrated that both factors inoculum type and dilution level had significant effects on $P$. patula seedling growth. The treatments with undiluted inocula were most effective for promoting seedling growth; nevertheless, the most significant growth was still lower than that reported for other species ( $P$. maximinoii, $P$. oocarpa, and $P$. tecunumanii) $[19,20]$.

Root ectomycorrhizal colonization was measurable for all treatments despite the dilution treatment; however, it was incipiently developed with the most diluted treatments. The results of this study support the idea that plant growth is 
TABLE 2: Mean values for plant height, root ectomycorrhizal colonization, root collar diameter, and shoot dry weight in response to interaction between inocula $(I)$ and dilution factors $(D)$. Standard deviations appear between parentheses.

\begin{tabular}{|c|c|c|c|c|c|}
\hline Inoculum & Dilution & Plant height $(\mathrm{cm})$ & Shoot dry weight (g) & Root collar diameter $(\mathrm{mm})$ & Ectomycorrhizal colonization (\%) \\
\hline \multirow{7}{*}{ ES } & $10^{0}$ & $4.4(0.2)$ & $0.9(0.1)$ & $1.5(0.0)$ & $23.6(2.3)$ \\
\hline & $10^{-1}$ & $4.3(0.3)$ & $0.8(0.1)$ & $1.4(0.0)$ & $22.4(3.0)$ \\
\hline & $10^{-2}$ & $4.1(0.3)$ & $0.8(0.1)$ & $1.4(0.0)$ & $21.2(3.1)$ \\
\hline & $10^{-3}$ & $4.0(0.1)$ & $0.8(0.1)$ & $1.4(0.0)$ & $19.4(2.6)$ \\
\hline & $10^{-4}$ & $4.0(0.2)$ & $0.7(0.1)$ & $1.4(0.0)$ & $17.8(2.5)$ \\
\hline & $10^{-5}$ & $3.8(0.3)$ & $0.7(0.1)$ & $1.4(0.0)$ & $16.6(3.4)$ \\
\hline & $10^{-6}$ & $3.7(0.2)$ & $0.6(0.1)$ & $1.3(0.0)$ & $15.8(2.6)$ \\
\hline \multirow{7}{*}{ EM } & $10^{0}$ & $5.6(0.9)$ & $1.1(0.3)$ & $1.5(0.0)$ & $31.6(5.1)$ \\
\hline & $10^{-1}$ & $5.6(1.0)$ & $0.9(0.1)$ & $1.5(0.0)$ & $26.6(3.5)$ \\
\hline & $10^{-2}$ & $4.5(0.5)$ & $0.8(0.1)$ & $1.5(0.0)$ & $22.8(3.7)$ \\
\hline & $10^{-3}$ & $4.3(0.3)$ & $0.8(0.1)$ & $1.4(0.0)$ & $21.6(4.4)$ \\
\hline & $10^{-4}$ & $4.1(0.5)$ & $0.8(0.1)$ & $1.4(0.1)$ & $17.8(3.4)$ \\
\hline & $10^{-5}$ & $4.1(0.6)$ & $0.8(0.1)$ & $1.4(0.1)$ & $15.8(2.7)$ \\
\hline & $10^{-6}$ & $3.9(0.7)$ & $0.7(0.1)$ & $1.4(0.1)$ & $10.4(2.9)$ \\
\hline \multicolumn{6}{|c|}{ ANOVA summary } \\
\hline \multicolumn{2}{|c|}{ Inocula $(I)$} & $<0.001$ & $<0.001$ & $<0.001$ & $<0.001$ \\
\hline \multicolumn{2}{|c|}{ Dilution $(D)$} & $<0.001$ & $<0.001$ & $<0.001$ & $<0.001$ \\
\hline \multicolumn{2}{|c|}{$I \times D$} & $<0.0001$ & $<0.01$ & 0.952 & 0.952 \\
\hline \multicolumn{2}{|c|}{ LSD } & 0.25 & 0.07 & 0.03 & 3.28 \\
\hline
\end{tabular}

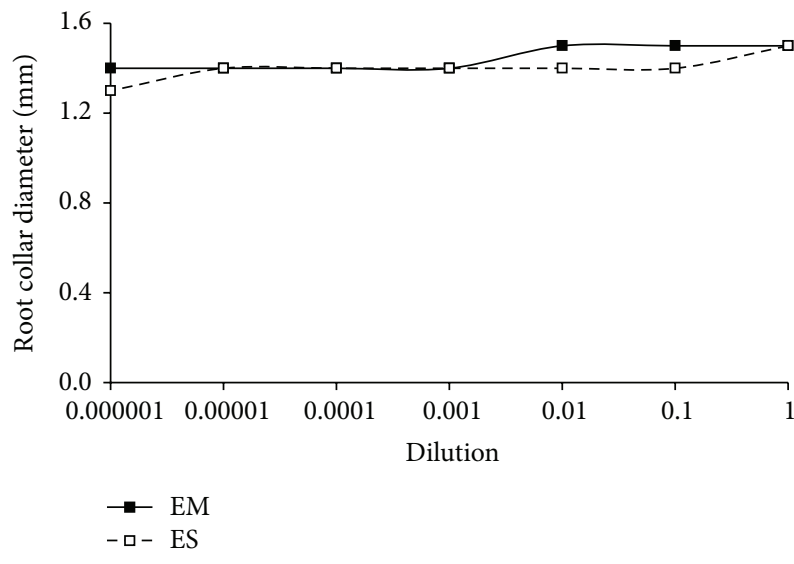

FIGURE 4: Root collar diameter of $P$. patula seedlings as a function of EM and ES inoculation at each level of serial dilution.

dependent on root ectomycorrhizal colonization, as reported for species such as $P$. pinaster [8], $P$. pinea [21], and $P$. thunbergii [22], and the values for ectomycorrhizal colonization are comparable with those reported $[19,20]$. The differences in root ectomycorrhizal colonization levels seem to be in turn determined by the EPD level of the inocula tested (ES inoculum $=34$ per $g$ and $E M$ inoculum $=156$ per g). However, it is worth mentioning that the ectomycorrhizal colonization may also vary with soil nutrient availability (particularly P), fertilization practices in nurseries, and fungicide application, among other conditions [23-25].

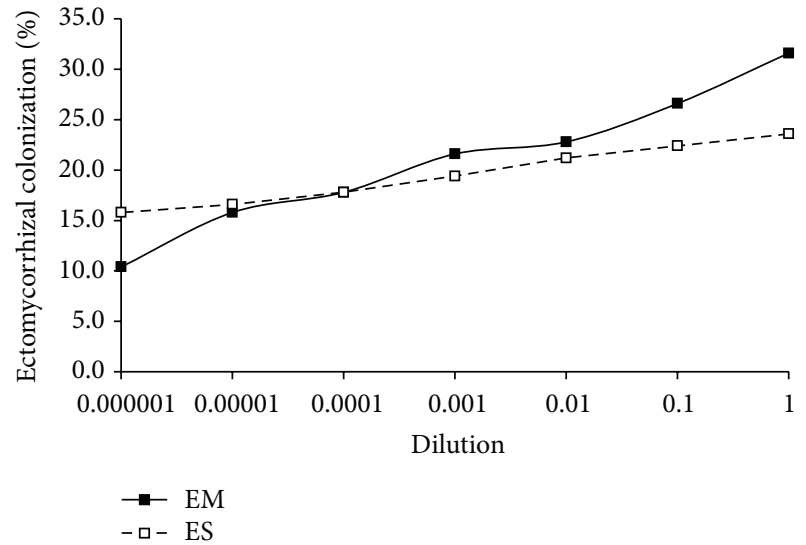

FIGURE 5: Root ectomycorrhizal colonization of $P$. patula seedlings for EM and ES inocula at each level of serial dilution.

Our findings indicate that the MPN technique was useful for determining the amount of ectomycorrhizal propagules in each inoculum and plant growth responses. The results of this method indicated that the best inoculum was EM, which was produced under in vitro conditions [14]. In contrast, the ES inoculum had a low EPD value and was a lower quality inoculum source. This is significant because inoculation with a high EPD (156) inoculum during the nursery stage can yield a satisfactory $P$. patula seedling quality, but with a low EPD (34) inoculum plant performance may be constrained; in fact, the results of plant growth with ES inoculum were even lower 
than those of EM-inoculated seedlings. In the case of ES inoculum, it appears that soil substrates extracted from forest plantations are usually low-density inocula. Thus, the EPD values of inocula dictated root ectomycorrhizal colonization trends; in fact, the values with undiluted inocula $\left(10^{\circ}\right)$ were of $31.6 \%(\mathrm{EM})$ and $23.6 \%$ (ES).

Independently of several factors affecting ectomycorrhizal establishment [27] as well as colonization by opportunistic ectomycorrhizal fungi commonly present in forestry nurseries $[21,28,29]$, our results reinforce the idea that the achievement of high values for root ectomycorrhizal colonization strongly depends on the inoculum EPD [21]. Despite the fact that all seedlings exhibited root ectomycorrhizal colonization, the values observed were lower than those reported in other studies with Pinus species. For instance, Sousa et al. [8] reported colonization values ranging from 40 to $70 \%$ in the roots of $P$. pinaster seedlings inoculated with mixed and individual fungi and Rincón et al. [21] reported that $P$. pinea seedlings growing in peat/vermiculite substrates reached higher values for root ectomycorrhizal colonization when inoculated with Rhizopogon luteolus $(>80 \%$; $2 \times 10^{7}$ spores $\left.\mathrm{mL}^{-1}\right)$ and Scleroderma verrucosum ( $57 \%$; $16 \times 10^{8}$ spores $\left.\mathrm{g}^{-1}\right)$. Castrillón et al. [20] reported with mixed inocula values of root ectomycorrhizal colonization in seedlings of P. oocarpa of $43.8 \%$ with Suillus luteus + Amanita sp., 39.9\% for $P$. tecunumanii with $S$. luteus + A. muscaria, and $38.1 \%$ for $P$. patula with S. luteus + Amanita sp. Reports suggest that EPD-rich inocula are most efficient at promoting colonization in Pinus seedling roots and may achieve values for root ectomycorrhizal colonization reaching $50 \%$ or higher values $[21,30,31]$.

Meanwhile, another key factor that may affect root colonization is a low compatibility between plant and fungus species [5,24,26, 32-35]. The effectiveness and specificity of $P$. patula-fungus relationships have been little studied and their role in plant growth remains unclear. Future research must be conducted to test this as well as to determine the effectiveness of the combined use of ectomycorrhizal fungi and other plant promoting-growth microorganisms.

In summary, the results suggest that the MPN method is a valuable tool for assessing the effectiveness of inocula at promoting root colonization in P. patula seedlings and promoting plant growth during the nursery stage. This method allowed us to identify inocula into different quality categories, taking into account the EPD value. Our results suggest that the EPD value of an inoculum is a key factor in root colonization. The low EPD value present in the ES inoculum indicates that the extraction of soil from forest plantations may be considered as an ineffective practice for promoting both root colonization and plant growth. On the other hand, the high EPD obtained from the EM inoculum reinforced the thesis of using a high quality inoculum for forest nurseries. From the practical point of view, the MPN technique provides a simple tool to identify the effectiveness of a potential source of ectomycorrhizal inoculum. This may be used by ectomycorrhizal inoculum producers, nursery seedling producers, and governmental agencies that regulate the quality of inocula.

\section{Conflict of Interests}

The authors declare that there is no conflict of interests regarding the publication of this paper.

\section{Acknowledgments}

The authors are grateful to COLCIENCIAS, Young Scientists Program, Gobernación de Antioquia, Knowledge Generation Program, and the Universidad Nacional de Colombia for financial support to Manuel Restrepo-Llano.

\section{References}

[1] C. Kuek, "Issues concerning the production and use of inocula of ectomycorrhizal fungi," in Management of Mycorrhizas in Agriculture, Horticulture and Forestry, A. D. Robson, L. K. Abbott, and N. Malajczuk, Eds., pp. 221-230, Kluwer Academic Publishers, Dordrecht, The Netherlands, 1994.

[2] G. Hawley, Ectomycorrhizal characterization, species diversity and community dynamics in Pinus patula Schelecht. et Cham. plantations [Ph.D. thesis], Rhodes University, Grahamstown, South Africa, 2006.

[3] P. Agarwal and O. Sah, "Ecological importance of ectomycorrhizae in world forest ecosystems," Nature and Science, vol. 7, pp. 107-116, 2009.

[4] F. Cubbage, S. Koesbandana, P. M. Donagh et al., "Global timber investments, wood costs, regulation, and risk," Biomass \& Bioenergy, vol. 34, no. 12, pp. 1667-1678, 2010.

[5] V. Mohan, K. Natarajan, and K. Ingleby, "Anatomical studies on ectomycorrhizas. III. The ectomycorrhizas produced by Rhizopogon luteolus and Scleroderma citrinum on Pinus patula," Mycorrhiza, vol. 3, no. 2, pp. 51-56, 1993.

[6] M. Brundrett, "Diversity and classification of mycorrhizal associations," Biological Reviews, vol. 79, no. 3, pp. 473-495, 2004.

[7] M. de Roman, V. Claveria, and A. M. de Miguel, "A revision of the descriptions of ectomycorrhizas published since 1961," Mycological Research, vol. 109, no. 10, pp. 1063-1104, 2005.

[8] N. R. Sousa, A. R. Franco, R. S. Oliveira, and P. M. L. Castro, "Ectomycorrhizal fungi as an alternative to the use of chemical fertilisers in nursery production of Pinus pinaster," Journal of Environmental Management, vol. 95, pp. S269-S274, 2012.

[9] P.-E. Courty, M. Buée, A. G. Diedhiou et al., "The role of ectomycorrhizal communities in forest ecosystem processes: new perspectives and emerging concepts," Soil Biology and Biochemistry, vol. 42, no. 5, pp. 679-698, 2010.

[10] A. Dahlberg and R. Finlay, "Suillus," in Ectomycorrhizal Fungi: Key Genera in Profile, J. Cairney and S. Chambers, Eds., pp. 3364, Springer, Berlin, Germany, 1999.

[11] W. G. Cochran, "Estimation of bacterial densities by means of the "most probable number"', Biometrics, vol. 6, no. 2, pp. 105116, 1950.

[12] N. A. Sawyer, S. M. Chambers, and J. W. G. Cairney, "Distribution and persistence of Amanita muscaria genotypes in Australian Pinus radiata plantations," Mycological Research, vol. 105, no. 8, pp. 966-970, 2001.

[13] M. Rudawska, T. Leski, L. K. Trocha, and R. Gornowicz, "Ectomycorrhizal status of Norway spruce seedlings from bareroot forest nurseries," Forest Ecology and Management, vol. 236, no. 2-3, pp. 375-384, 2006. 
[14] I. Repác, "Ectomycorrhizal inoculum and inoculation techniques," in Diversity and Biotechnology of Ectomycorrhizae, M. Rai and A. Varma, Eds., pp. 43-63, Springer, Berlin, Germany, 2011.

[15] M. Habte and W. Osorio, Arbuscular Mycorrhizas: Producing and Applying Arbuscular Mycorrhizal Inoculum, Department of Tropical Plant and Soil Sciences, University of Hawaii, Manoa, Hawaii, USA, 2001.

[16] J. F. Dames, C. J. Straker, and M. C. Scholes, "Ecological and anatomical characterization of some Pinus patula ectomycorrhizas from Mpumalanga, South Africa," Mycorrhiza, vol. 9, no. 1, pp. 9-24, 1999.

[17] M. Brundrett, N. Bougher, B. Dell, T. Grove, and N. Malajczuk, Working with Mycorrhizas in Forestry and Agriculture, Pirie Printers, Canberra, Australia, 1996.

[18] R Development Core Team, R: A Language and Environment for Statistical Computing, R Foundation for Statistical Computing, Vienna, Austria, 2011, http://www.r-project.org.

[19] C. Orozco-Jaramillo and P. Martínez-Nieto, "Evaluación de la inoculación con microorganismos fijadores de nitrógeno asimbióticos aislados de la rizósfera de Pinus patula en Colombia," Bosque, vol. 30, pp. 70-77, 2009.

[20] M. Castrillón, J. D. León, D. Carvajal, and N. W. Osorio, "Effectiveness of single and combined ectomycorrhizal inocula on three species of Pinus at nursery," Communications in Soil Science and Plant Analysis, 2014.

[21] A. Rincón, J. Parladé, and J. Pera, "Effects of ectomycorrhizal inoculation and the type of substrate on mycorrhization, growth and nutrition of containerised Pinus pinea L. seedlings produced in a commercial nursery," Annals of Forest Science, vol. 62, no. 8, pp. 817-822, 2005.

[22] T. Taniguchi, R. Kataoka, and K. Futai, "Plant growth and nutrition in pine (Pinus thunbergii) seedlings and dehydrogenase and phosphatase activity of ectomycorrhizal root tips inoculated with seven individual ectomycorrhizal fungal species at high and low nitrogen conditions," Soil Biology \& Biochemistry, vol. 40, no. 5, pp. 1235-1243, 2008.

[23] T. Laatikainen and H. Heinonen-Tanski, "Mycorrhizal growth in pure cultures in the presence of pesticides," Microbiological Research, vol. 157, no. 2, pp. 127-137, 2002.

[24] U. Ortega, M. Duñabeitia, S. Menendez, C. Gonzalez-Murua, and J. Majada, "Effectiveness of mycorrhizal inoculation in the nursery on growth and water relations of Pinus radiata in different water regimes," Tree Physiology, vol. 24, no. 1, pp. 6573, 2004.

[25] J. Liang, Z. Sun, Z. Qu, Y. Zhang, Q. Lu, and X. Zhang, "Long-term effect of an ectomycorrhizal inoculum and other treatments on survival and growth of Populus hopeiensis $\mathrm{Hu}$ et Chow," Forest Ecology and Management, vol. 259, no. 12, pp. 2223-2232, 2010.

[26] Y. L. Chen, L. H. Kang, and B. Dell, "Inoculation of Eucalyptus urophylla with spores of Scleroderma in a nursery in South China: comparison of field soil and potting mix," Forest Ecology and Management, vol. 222, no. 1-3, pp. 439-449, 2006.

[27] B. Kieliszewska-Rokicka, M. Rudawska, and T. Leski, "Ectomycorrhizae of young and mature Scots pine trees in industrial regions in Poland," Environmental Pollution, vol. 98, no. 3, pp. 315-324, 1997.

[28] C. E. Cordell, J. H. Owen, and D. H. Marx, "Mycorrhizae nursery management for improved seedling quality and field performance," in Proceedings of the Meeting the Challenge of the Nineties, pp. 105-115, Intermountain Forest Nursery Association, Oklahoma City, Okla, USA, 1987.

[29] M. Iwański, M. Rudawska, and T. Leski, "Mycorrhizal associations of nursery grown Scots pine (Pinus sylvestris L.) seedlings in Poland," Annals of Forest Science, vol. 63, no. 7, pp. 715-723, 2006.

[30] F. Martin, S. Duplessis, F. Ditengou, H. Lagrange, C. Voiblet, and F. Lapeyrie, "Developmental cross talking in the ectomycorrhizal symbiosis: signals and communication genes," New Phytologist, vol. 151, no. 1, pp. 145-154, 2001.

[31] U. Nehls, N. Grunze, M. Willmann, M. Reich, and H. Küster, "Sugar for my honey: carbohydrate partitioning in ectomycorrhizal symbiosis," Phytochemistry, vol. 68, no. 1, pp. 82-91, 2007.

[32] A. Yamada and K. Katsuya, "Mycorrizal association of isolates from sporocarps and ectomycorrhizas with Pinus densiflora seedlings," Mycoscience, vol. 40, pp. 455-463, 1995.

[33] K. Haselwandter and G. D. Bowen, "Mycorrhizal relations in trees for agroforestry and land rehabilitation," Forest Ecology and Management, vol. 81, no. 1-3, pp. 1-17, 1996.

[34] L. Qu, A. Quoreshi, K. Iwase, Y. Tamai, R. Funada, and T. Koike, "In vitro ectomycorrhiza formation on two larch species of seedlings with six different fungal species," Eurasian Journal of Forest Research, vol. 6, pp. 65-73, 2003.

[35] A. M. Quoreshi and D. P. Khasa, "Effectiveness of mycorrhizal inoculation in the nursery on root colonization, growth, and nutrient uptake of aspen and balsam poplar," Biomass and Bioenergy, vol. 32, no. 5, pp. 381-391, 2008. 

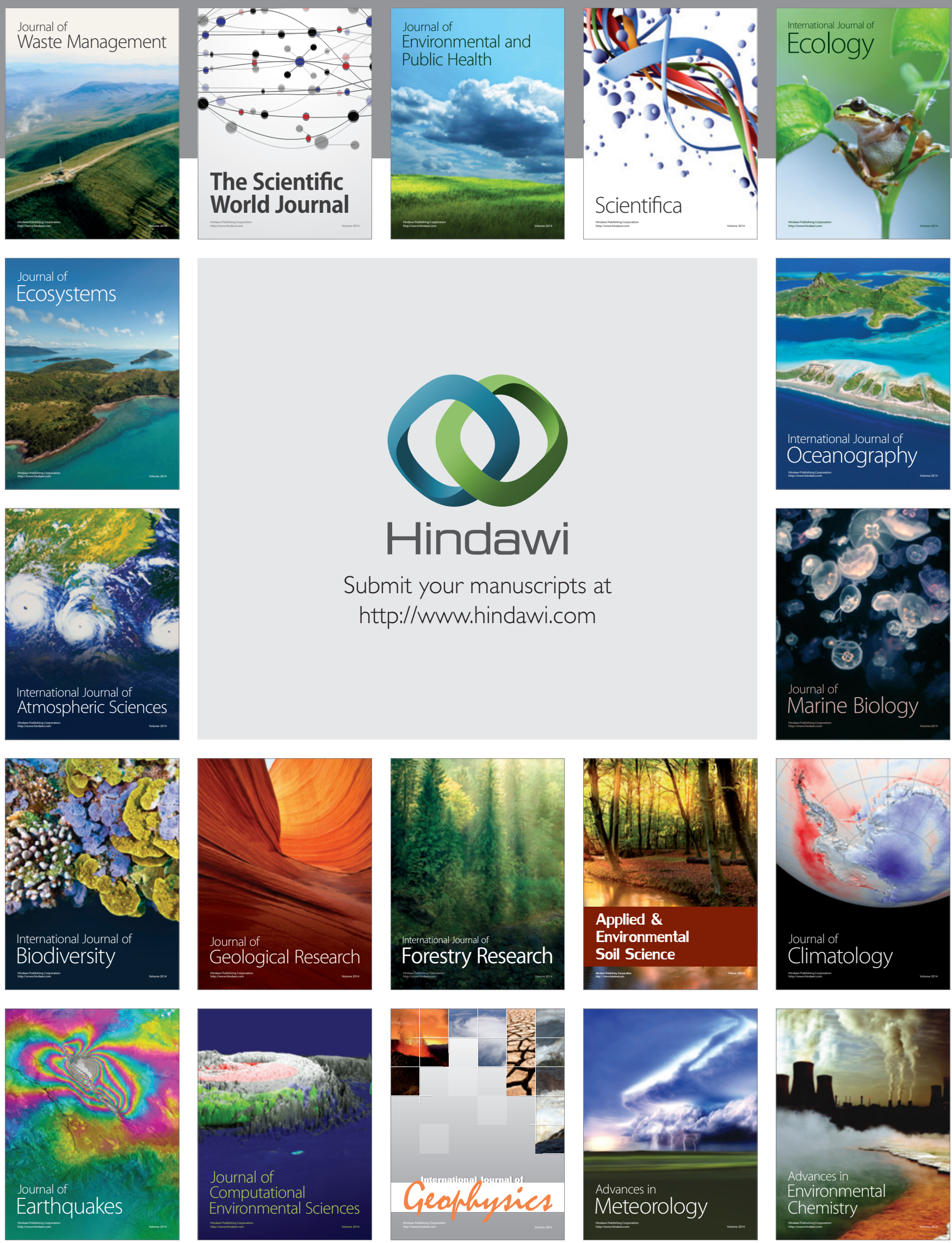